\title{
Comparison of oximeters for the detection of critical congenital heart diseases
}

\section{Comparación de oxímetros para detección de cardiopatías congénitas críticas}

\author{
Rocío A. Peña-Juárez ${ }^{1 *}$, Jorge A. Chávez-Saenz², Adrián García-Canales², \\ Miguel A. Medina-Andrade1, María T. Martínez-González², Lorenzo Gutiérrez-Cobián ${ }^{1}$, \\ Daniela A. Mendoza-Silva², Cesar A. Valerio-Carballo', and Antonio F. Gallardo-Meza ${ }^{2}$ \\ ${ }^{1}$ Department of Pediatric Cardiology, Hospital General de Occidente, Zapopan, Jalisco, Mexico; ${ }^{2}$ Department of Pediatrics, Hospital General de \\ Occidente, Zapopan, Jalisco, Mexico
}

\begin{abstract}
Introduction and objectives: In some centers, the pulse oximetry is not performed with the justification of lack of the adequate oximeter. We compared the effectiveness of two brands of oximeters to perform it. Methods: In neonates, a term of the joint housing service of the Hospital General de Occidente in Zapopan, Jalisco, Mexico, from May to November 2018, an examination of the characteristics of the American Academy of Pediatrics with both oximeters (ChoiceMMed ${ }^{\circledR}$ and Masimo SET ${ }^{\circledR}$ ) was carried out, comparing the detection of critical congenital heart disease, time of intake, and false positives. Results: In each group, 1022 patients were analyzed; with the Masimo SET ${ }^{\circledR}$ oximeter, 83 positive tests were obtained (8.12\%), of which 22 cases had some heart disease (26.5\%), which represents a sensitivity of $100 \%$, specificity of $93.9 \%$, positive predictive value of $26.5 \%$, and negative predictive value of $100 \%$ (odds ratio [OR]: 0.73; 95\% confidence interval [Cl]: 0.6-0.8). With the ChoiceMMed® oximeter, 168 positive tests were obtained (16.4\%), of which 22 cases had some heart disease (13.09\%), with a sensitivity of $100 \%$, specificity of $85.4 \%$, positive predictive value of $13.09 \%$, and negative predictive value $100 \%$ (OR: 0.86; 95\% Cl: 0.8-0.92). Regarding the time to perform the cardiac sieve, the mean in minutes of the Masimo SET ${ }^{\circledR}$ oximeter was 5.38 and the ChoiceMMed ${ }^{\circledR}$ oximeter was 9.7 min. Conclusions: The ChoiceMMed ${ }^{\circledR}$ oximeter contains a large number of false positives and a greater number of echocardiograms and comparatively longer cardiac screen printing with Masimo SET ${ }^{\circledR}$, however, both with a negative predictive value of $100 \%$ eliminating such excuses.
\end{abstract}

Key words: Pulse oximetry. Congenital heart disease. Critical illness.

\section{Resumen}

Introducción y objetivos: En algunos centros el tamiz cardíaco no se realiza con la justificación de no tener el oxímetro adecuado. Comparamos la efectividad de dos marcas de oxímetros para realizarlo. Métodos: En los neonatos a término del Servicio de alojamiento conjunto del Hospital General de Occidente en Zapopan Jalisco México de mayo a noviembre del 2018 se realizó tamiz cardíaco según las guías de la Academia Americana de Pediatría con dos oxímetros, el Masimo SET ${ }^{\circledR}$

\section{Correspondence:}

*Rocío Alejandra Peña-Juárez

Department of Pediatric Cardiology

Hospital General de Occidente

Av. Zoquipan 1050, Col. Seattle

Date of reception: 02-01-2019

Date of acceptance: 24-02-2019

E-mail: alepejz@gmail.com

DOI: 10.24875/ACME.M19000039
Available online: 30-10-2019 Arch Cardiol Mex (Eng). 2019;89(2):159-166 www.archivoscardiologia.com 2604-7063 @ 2019 Instituto Nacional de Cardiología Ignacio Chávez. Published by Permanyer México SA de CV. This is an open access article under the CC BY-NC-ND license (http://creativecommons.org/licenses/by-nc-nd/4.0/). 
(aprobado por la FDA) y el ChoiceMMed ${ }^{\circledR}$, comparando su efectividad para la detección de cardiopatías congénitas críticas, el tiempo de toma y los falsos positivos. Resultados: En cada grupo se analizaron 1,022 pacientes; con el oxímetro Massimo SET $T^{\circledast}$ se obtuvieron 83 pruebas positivas $(8.12 \%$ ) de las cuales 22 casos presentaron alguna cardiopatía (26.5\%), lo que representa una sensibilidad del $100 \%$, una especificidad del $93.9 \%$, un valor predictivo positivo del $26.5 \%$ y un valor predictivo negativo del 100\% (Odd Ratio [OR]: 0.73; IC 95\%: 0.6-0.8). Con el oxímetro ChoiceMMed ${ }^{\boxplus}$ se obtuvieron 168 pruebas positivas (16.4\%), de las cuales 22 casos presentaron alguna cardiopatía (13.09\%), con una sensibilidad del 100\%, una especificidad del $85.4 \%$, un valor predictivo positivo del $13.09 \%$ y un valor predictivo negativo del $100 \%$ (OR: 0.86; IC 95\%: 0.8-0.92). En cuanto al tiempo para realizar el tamiz cardíaco, la media en minutos del oxímetro Masimo $S E T^{\circledR}$ fue 5.38 y del oxímetro ChoiceMMed ${ }^{\circledR}$ fue 9.7 minutos. Conclusiones: El oxímetro ChoiceMMed ${ }^{\circledR}$ presentó mayor cantidad de falsos positivos y mayor tiempo de realización del tamiz cardíaco en comparación al Masimo SET ${ }^{\circledR}$, sin embargo, ambos presentan un valor predictivo negativo del 100\%, siendo igualmente útiles como método de detección de cardiopatías críticas.

Palabras clave: Oximetría de pulso. Cardiopatía congénita. Enfermedad crítica.

\section{Introduction}

Critical congenital heart diseases (CCHDs) are considered a high-risk factor for cardiovascular collapse or even death ${ }^{1}$. Critical heart diseases prevalence, epidemiology, and late impact on diagnosis have been described in several publications ${ }^{2}$. CCHDs affect approximately two of every 1000 births, and it is, therefore, estimated that around 40,000 babies are born with any CCHD every year in the US alone and 1.35 million around the world. These heart conditions represent around $40 \%$ of deaths caused by congenital malformations and the majority of deaths from cardiovascular disease that occurs in the $1^{\text {st }}$ year of life $^{3}$. In Mexico, between 1990 and 2010, child mortality decreased from $24 \%$ to $11.8 \% / 1000$ births. However, mortality from congenital heart diseases has increased. In the year 2000, mortality from congenital heart diseases was 2596 children younger than 1 year, which accounted for $6.7 \%$ of all deaths in this age group. In 2008, mortality associated with congenital heart diseases increased to 2848 children, corresponding to $9.6 \%$ of total deaths. In addition, $30 \%$ of deaths from CCHD are known to be attributed to diagnostic errors or late diagnosis ${ }^{4}$. A common denominator of CCHDs is the presence of hypoxemia with consequent as cyanosis, which is not perceptible to the naked eye in all newborns (NBs); therefore, carrying out non-invasive studies for early detection of these patients has been necessary. In 2009, Granelli et al. ${ }^{5}$, in a group of $39,821 \mathrm{NBs}$, introduced pulse oximetry for the detection of CCHD with an adequate sensitivity. Subsequently, the American Academy of Pediatrics, together with the American Heart Association ${ }^{6}$, determined that some patients with critical heart diseases were not detected before hospital discharge, resulting in high morbidity and mortality. Therefore, systematically performing pulse oximetry in asymptomatic NBs after the first $24 \mathrm{~h}$ of life, but before hospital discharge, was recommended to detect critical heart conditions (Fig. 1). From that moment on, pulse oximetry was established as a useful, non-invasive, and low-cost tool for the detection of these patients. Efforts are being made in our country for the mandatory performance of pulse oximetry screening for CCHD; however, the procedure is not yet mandatory. One of the main obstacles to carrying it out is the pulse oximeter, whereby the screening is performed since there are multiple known factors that may affect accuracy, such as movement, low perfusion, electromagnetic interference, interference with ambient light, hemoglobin variants, and height, among others ${ }^{7}$. Specific characteristics of the pulse oximetry measuring device should be considered to perform the CCHD screening, including8:

- It should comply with the standards of the International Organization for Standardization and be approved by the Food and Drug Administration (FDA) for hospital use in NBs.

- Is must adapt to patient movement and have an adequate performance in real situations.

- It should have the recommended sensors for placement on neonatal limbs without the need for fixing means that might affect skin integrity. Adult sensors should not be used in NBs.

- Using the indicated sensors for each monitor must be ensured.

So far, only two pulse oximetry measuring devices that meet the requirements recommended by the FDA are available: the Masimo $\mathrm{SET}^{\circledR}$ oximeter and the Covidien $\mathrm{Nellcor}^{\circledR}$ oximeter ${ }^{9}$; however, only few centers in our country have any of them since their cost is high. One of the most widely used devices in the hospital setting is the ChoiceMMed ${ }^{\circledR}$ oximeter, which is not endorsed by the FDA for CCHD screening but is one of the most commonly used for this purpose. The objective of our study is to assess whether the ChoiceMMed $^{\circledR}$ oximeter has similar efficacy as a screening 


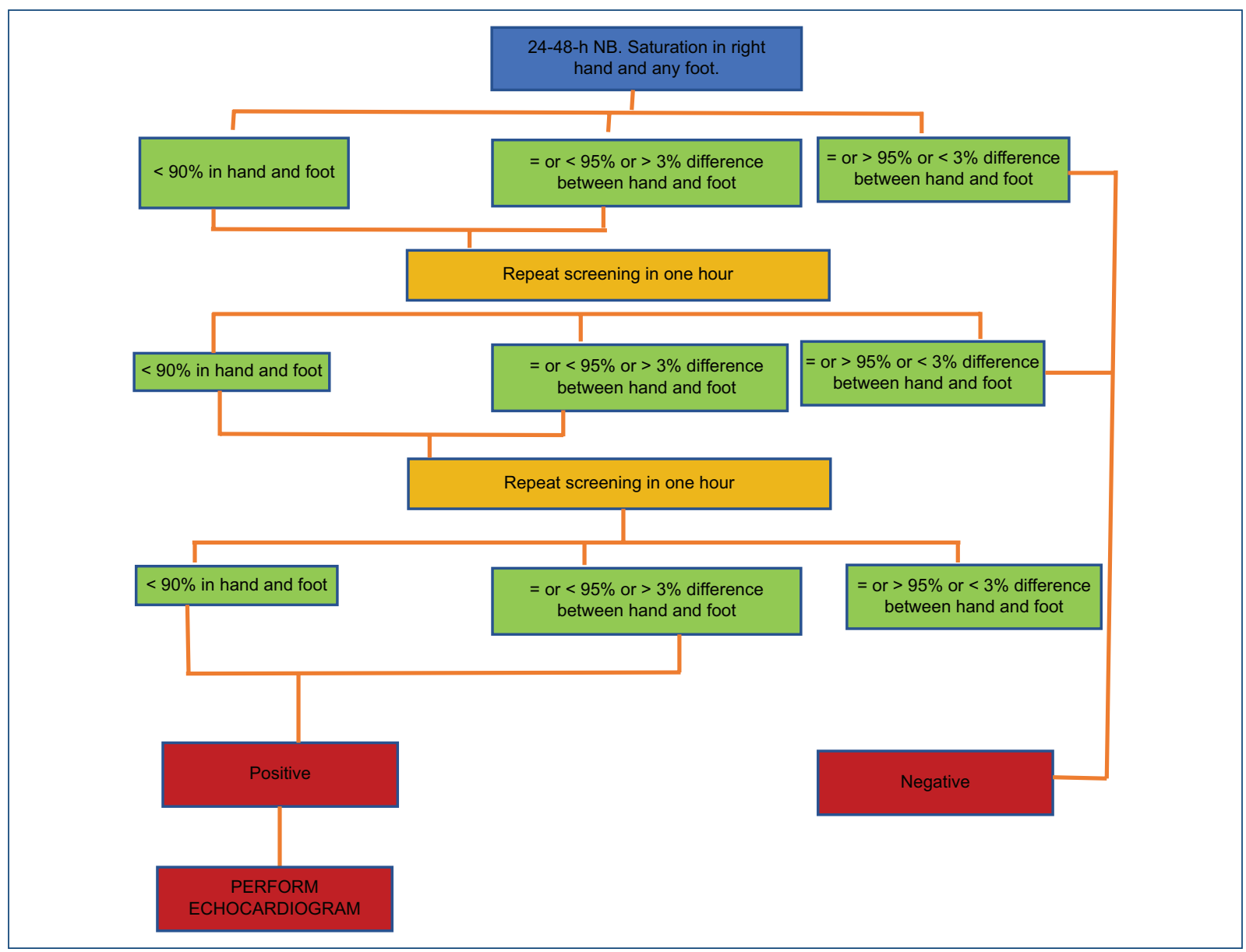

Figure 1. Algorithm for cardiologic screening. The American Academy of Pediatrics (adapted from Martin et al., 2013). NB: newborn.

method for CCHD in comparison with one of the FDA-approved oximeters (Masimo SET ${ }^{\circledR}$ ).

\section{Methods}

This was a prospective, longitudinal, observational study that was carried out from March to November 2018 at the maternity ward of the General Hospital of the West in Guadalajara, Jalisco, Mexico. Full-term NBs (37-41.6 weeks of gestation), with adequate weight for gestational age (more than $2500 \mathrm{~g}$ ) and older than $24 \mathrm{~h}$ of life, who were in the maternity ward, were included in the study. They were assessed by pediatricians and pediatric cardiologists, who performed the oximetry test according to the American Academy of Pediatrics protocol. The test consists of pre- and post-ductal pulse oximetry measurement (upper right limb and any lower limb), after the first $24 \mathrm{~h}$ of life, at the nursery, in apparently healthy full-term NBs. A result is considered positive if: (a) any saturation measurement is < $90 \%$; (b) oxygen saturation is < $<95 \%$ in both limbs in three measurements separated by 1 $\mathrm{h}$, or (c) if there is an absolute difference $>3 \%$ in oxygen saturation between the right hand and the foot in all three measurements, each one separated by $1 \mathrm{~h}$. Any measurement $>95 \%$ in any extremity with $<3 \%$ difference in oxygen saturation between the upper and lower limbs was to be considered a negative result and the examination would finish ${ }^{8,9}$ (Fig. 1). All patients who entered the study underwent cardiologic screening with both oximeters. For this, two medical teams were formed, which included a pediatrician and a pediatric cardiologist. Each one of the groups performed the oximetry tests with a different device; either with the Masimo SET ${ }^{\circledR}$ oximeter or with the ChoiceMMed ${ }^{\circledR}$ oximeter, and in addition to performing the oximetry test, a complete physical examination was carried out. As for echocardiographic evaluation, it was performed at the end of the assessment with both oximeters; these examinations were carried out with a Philips Epic $7^{\circledR}$ 


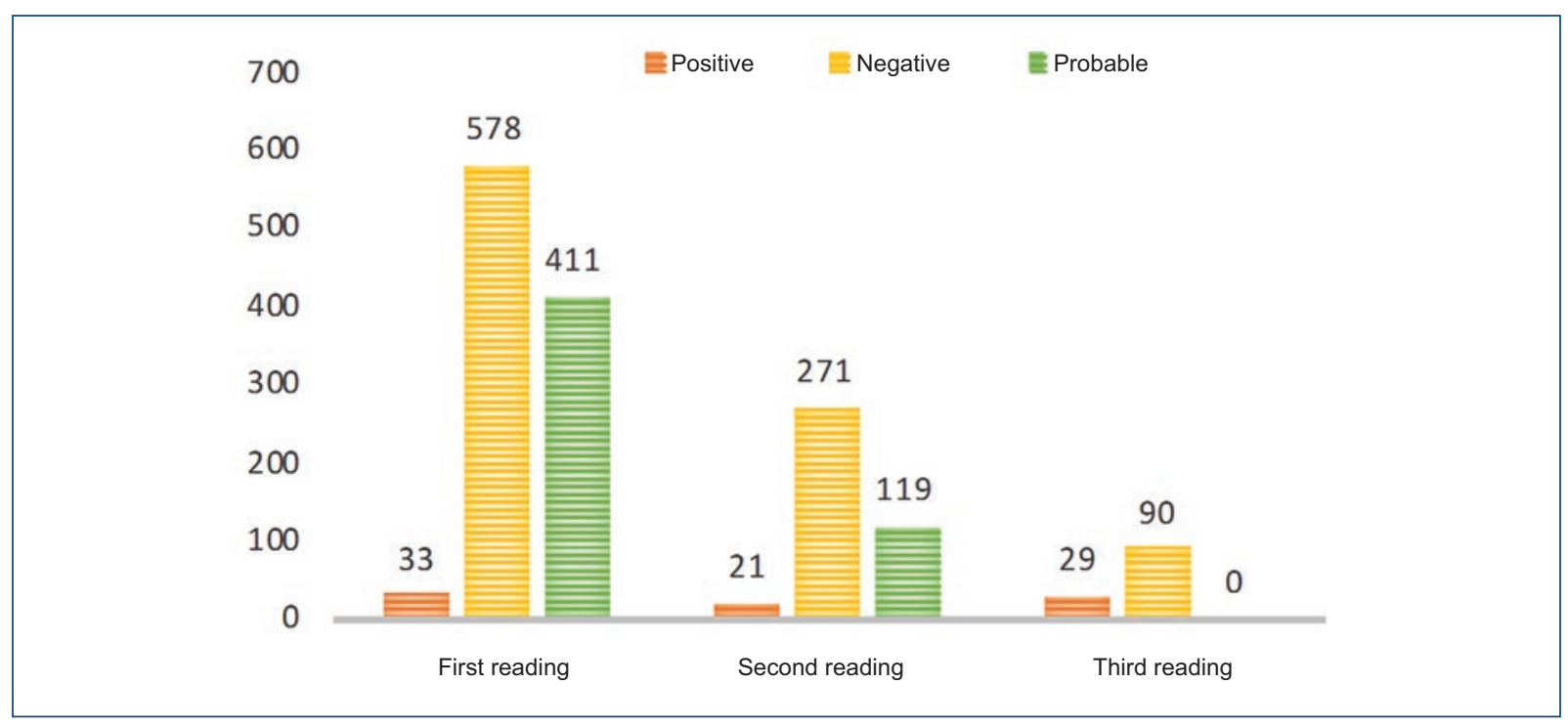

Figure 2. Cardiologic screening results on the three readings with the Masimo $\mathrm{SET}^{\circledR}$ oximeter.

equipment with a 1-5 $\mathrm{MHz}$ probe by a pediatric cardiologist. The study variables were the number of attempts (this based on the Masimo $\mathrm{SET}^{\circledR}$ oximeter, by means of which the test is performed in $3 \mathrm{~min})$, positive tests, false-positive tests, and echocardiogram performance in both groups. The study was approved by the Research and Ethics Committee of the hospital.

\section{Results}

During the study period, 1022 patients were evaluated. Average gestation age was $38.9 \pm 1.5$ weeks and

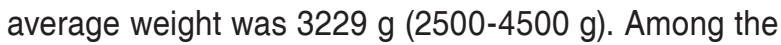
studied patients, 518 were male (50.7\%); 64.7\% ( $n=661$ ) were delivered by cesarean section, and in $98.8 \%$ of cases, pregnancy was single. The presence of maternal pathology was assessed, which was found in $2.3 \%$ of our population, with the most common being gestational diabetes (38\%), followed by pre-eclampsia (30\%), hypothyroidism (17\%), and asthma, lupus, and HELLP syndrome (4.1\% each).

\section{Masimo SET ${ }^{\circledR}$ oximeter}

\section{FIRST READING}

The first oximetry test included 1022 patients; average pre-ductal saturation was $96.7 \%$ (81.9-100\%) and average post-ductal saturation was $94.8 \%$ (78.3-99.8\%), with an average saturation difference of $1.9 \%$ (6.5-20.8\%). Regarding pre-ductal perfusion rates, the average was $2.5 \%$ (0.3$16)$ and post-ductal $2.18 \%(0.1-18.8 \%)$. Of the 1022 oximetry tests, 33 (3.2\%) were positive, 578 (56.5\%) were negative, and 411 (40.2\%) probable (Fig. 1). The echocardiographic results were normal 21 (63.6\%), pulmonary hypertension 4 (12.1\%), non-critical heart disease 5 (15.2\%), and critical heart disease $3(9.1 \%)$ (one transposition of the great arteries, one total abnormal connection of pulmonary veins, and one coarctation of the aorta). Three NBs were detected to have data consistent with sepsis and two having data consistent with pneumonia (Fig. 2).

\section{SECOND READING}

A total of 411 patients were included, of which $48.4 \%$ belong to the female gender. Average pre-ductal saturation was $96.38 \%$ (89-100\%), whereas post-ductal average was $94.99 \%$ (81.6-99.8\%). The saturation difference was $1.39 \%(1.4-10.3 \%)$, pre-ductal perfusion index was $2.44 \%(0.3-10.7 \%)$, and post-ductal perfusion index was $2.01 \%(0.2-10.1 \%)$. As for the results, 21 tests were positive $(5.1 \%), 271$ were negative (65.9\%), and 119 probable (29\%) (Fig. 1), and in the echocardiogram results, we found $24 \%(n=5)$ of non-critical heart diseases and 16 that were normal; in this group, three patients with data consistent with sepsis were identified (Fig. 2).

\section{THIRD READING}

One-hundred and nineteen oximetry tests were performed, of which $58 \%$ were in female subjects. Pre-ductal saturation average was 96\% (90.3-99.6\%) and post-ductal saturation average was $94.4 \%$ (89.7-98.7\%), 


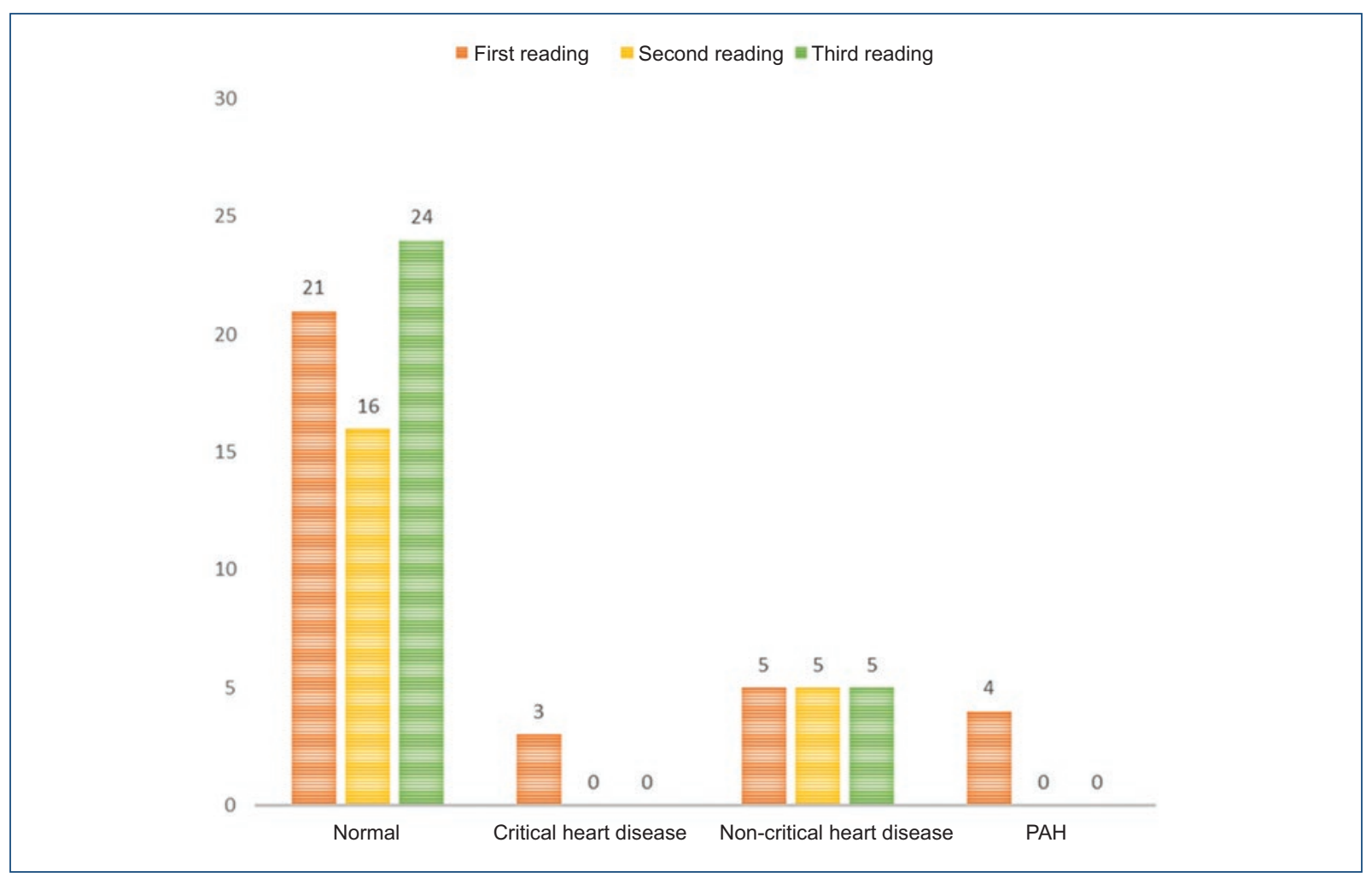

Figure 3. Echocardiographic results with the Masimo $\mathrm{SET}^{\circledR}$ oximeter.

PAH: pulmonary arterial hypertension.

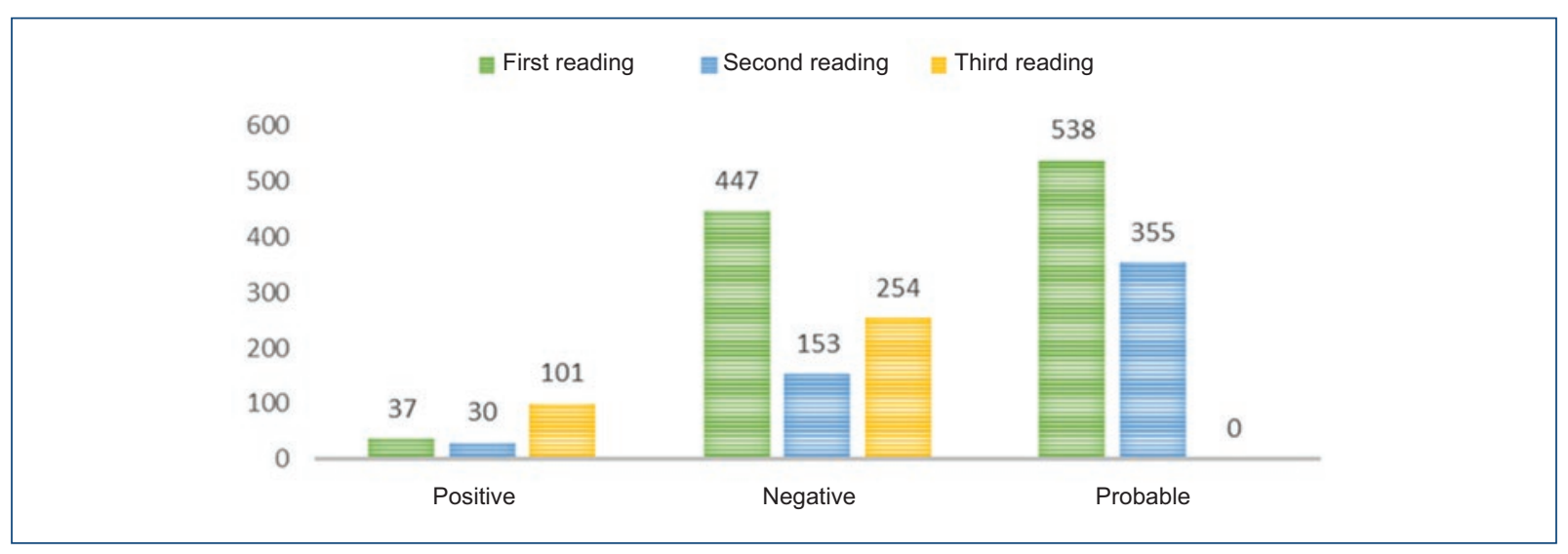

Figure 4. Cardiac screening test results with the ChoiceMMed ${ }^{\circledR}$ oximeter.

with the saturation difference being $1.6 \%(0.1-6.9 \%)$. Pre-ductal perfusion index was $2.5 \%$ (0.6-9.6\%), whereas post-ductal perfusion index was $2.1 \%(0.5-9.6 \%)$. As for the results, 29 tests were positive $(24.3 \%)$, among which only 5 patients $(17.2 \%)$ had any type of non-critical heart disease (Fig. 1). In the group of normal echocardiograms, two patients with data consistent with sepsis were detected (Fig. 2).

As for the number of attempts according to the oximeter program, which on average is $3 \mathrm{~min}$, in $60.1 \%$
(615 patients), it was only one attempt and in the rest only two attempts, with a mean time of $5.38 \mathrm{~min}$.

\section{ChoiceMMed ${ }^{\circledR}$ oximeter}

\section{FIRST READING}

A total of 1022 oximetry tests were performed, among which average pre-ductal saturation was 96\% (88$100 \%$ ) and post-ductal saturation was $93 \%$ (76-98\%). 
Table 1. Comparison of efficacy for the detection of critical congenital heart diseases with both oximeters

\begin{tabular}{|c|c|c|c|c|c|c|c|c|}
\hline Oximeter & $\begin{array}{l}\text { Total screened } \\
\text { subjects }\end{array}$ & $\begin{array}{l}\text { Positive } \\
\text { tests }\end{array}$ & $\begin{array}{l}\text { Abnormal } \\
\text { echoes }\end{array}$ & Sensitivity & Specificity & $\begin{array}{l}\text { Positive } \\
\text { predictive } \\
\text { value }\end{array}$ & $\begin{array}{l}\text { Negative } \\
\text { predictive } \\
\text { value }\end{array}$ & OR (95\% CI) \\
\hline Masimo SET ${ }^{\circledR}$ & 1022 & 83 & 22 & $100 \%$ & $93.9 \%$ & 26.5 & 100 & $0.73(0.6-0.8)$ \\
\hline ChoiceMMed $^{\circledR}$ & 1022 & 168 & 22 & $100 \%$ & $85.4 \%$ & 13.09 & 100 & $086(0.8-0.92)$ \\
\hline
\end{tabular}

Cl: confidence interval; OR: odds ratio.

Saturation difference was $2.3 \%(1.8-16.4 \%)$. As for the results, 37 tests were positive (3.6\%), $43.7 \%$ negative $(n=447)$, and the rest probable (Fig. 3). The echocardiogram results were normal in $34(91.9 \%)$, pulmonary arterial hypertension in $1(2.7 \%)$, critical heart disease in $1(2.7 \%)$ (pulmonary veins total anomalous connection), and non-critical heart disease in 1 (2.7\%) (Fig. 4). Two NBs with data consistent with sepsis and two with data consistent with pneumonia were detected.

\section{SECOND READING}

Five-hundred and thirty-eight oximetry tests were performed, of which 270 were in female patients $(50.18 \%)$. Average pre-ductal saturation was 95\% (90-99\%), whereas post-ductal saturation was $93 \%$ (81-99\%). As for saturation difference, the average was $2.42 \%(0-10.5 \%)$. Among total performed tests, only 30 were positive $(5.57 \%), 153$ were negative $(28.4 \%)$, and 355 probable (65.9\%) (Fig. 3). The echocardiogram results were as follows: critical heart disease in 1 (3.5\%) (transposition of the great arteries), non-critical heart disease in $1(3.5 \%)$, and the rest were normal (93.3\%) (Fig. 4). In addition, four patients with data consistent with sepsis were detected.

\section{THIRD READING}

A total of 355 oximetry tests were performed, of which $50.4 \%(n=179)$ were in female subjects. Average pre-ductal saturation was $94 \%(90-99 \%)$, whereas post-ductal saturation was $94 \%$ (86-97\%), with a saturation difference of $1.5 \%(0-7.8 \%)$. Among the oximetry test results, 101 (28.4\%) were positive (Fig. 3). As for the echocardiographic results, pulmonary arterial hypertension was observed in $3(2.9 \%)$, critical heart disease in $1(0.99 \%)$ (coarctation of the aorta), non-critical heart disease in 13 (12.87\%), and the rest were normal (Fig. 4). Two patients with data consistent with sepsis were detected.

Regarding the number of attempts, $15 \%(n=153)$ required one attempt, $37 \%(n=379)$ two attempts, $24.2 \%$ $(n=248)$ three attempts, and $23.8 \%(n=242)$ required more than four attempts, with a mean time of $9.7 \mathrm{~min}$.

\section{Positive tests}

With the Masimo SET ${ }^{\circledR}$ oximeter, of the 1022 oximetry tests that were performed, 83 were positive $(8.12 \%)$, of which 22 showed some type of heart disease (26.5\%), which represent a sensitivity of $100 \%$, specificity of $93.9 \%$, a positive predictive value of $26.5 \%$, and a negative predictive value of $100 \%$ (odds ratio [OR]: 0.73 ; 95\% confidence interval [Cl]: 0.6-0.8). In comparison with the ChoiceMMed $^{\circledR}$ oximeter, among 1022 oximetry tests performed, 168 were positive (16.4\%), of which 22 showed some cardiac alteration (13.09\%), with a sensitivity of $100 \%$, specificity of $85.4 \%$, a positive predictive value of $13.09 \%$, and a negative predictive value of 100\% (OR: 0.86; 95\% Cl: 0.8-0.92) (Table 1).

\section{Discussion}

Screening for CCHD detection has been indicated in the USA since September 201110; this is important because if these pathologies are not timely detected, they are associated with extremely high mortality ${ }^{11}$. In Mexi$\mathrm{co}$, cardiologic screening is not mandatorily regulated. One of the main "obstacles" that are reported is material issues and, especially, the elevated cost associated with its performance. Several studies have been carried out on the cost of cardiac screening, which report an average cost of $\$ 250$ pesos per patient; even in the study carried out in New Jersey, a lower cost, $\$ 92$ pesos, is referred, and it increases by $3 \%$ if echocardiography and transport are required according to a study carried out in Minnesota ${ }^{9,12-14}$. In contrast, treating an NB with a CCHD can entail a minimum of $\$ 895,000$ pesos $^{15}$, without this figure taking into account the high percentage of mortality in this group of patients, as previously mentioned. Therefore, the "elevated cost" associated with cardiac screening is no excuse for not performing it.

Another important point that is referred to as an obstacle to cardiac screening in some institutions is the device. In our study, we found that both oximeters have a negative predictive value of $100 \%$; this is very similar to the studies carried out by Riede et al. ${ }^{16}$, where pulse oximetry 


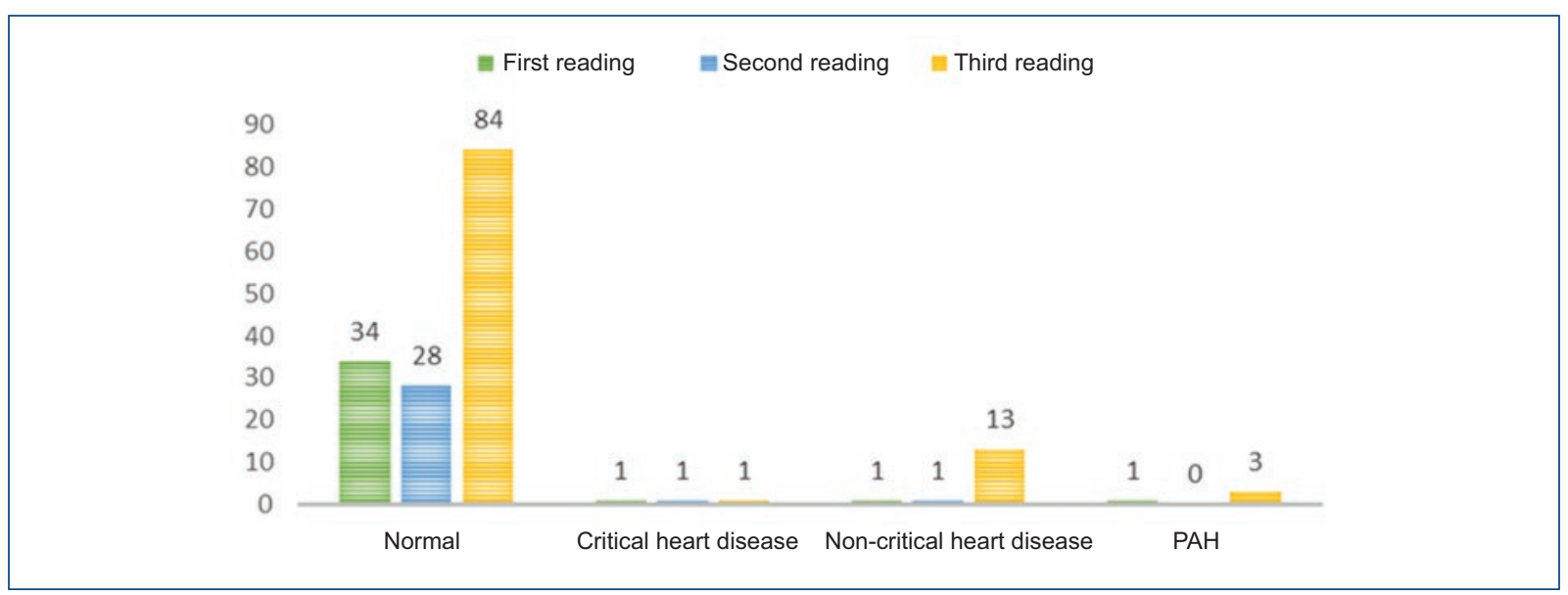

Figure 5. Echocardiographic results with the ChoiceMMed ${ }^{\circledR}$ oximeter.

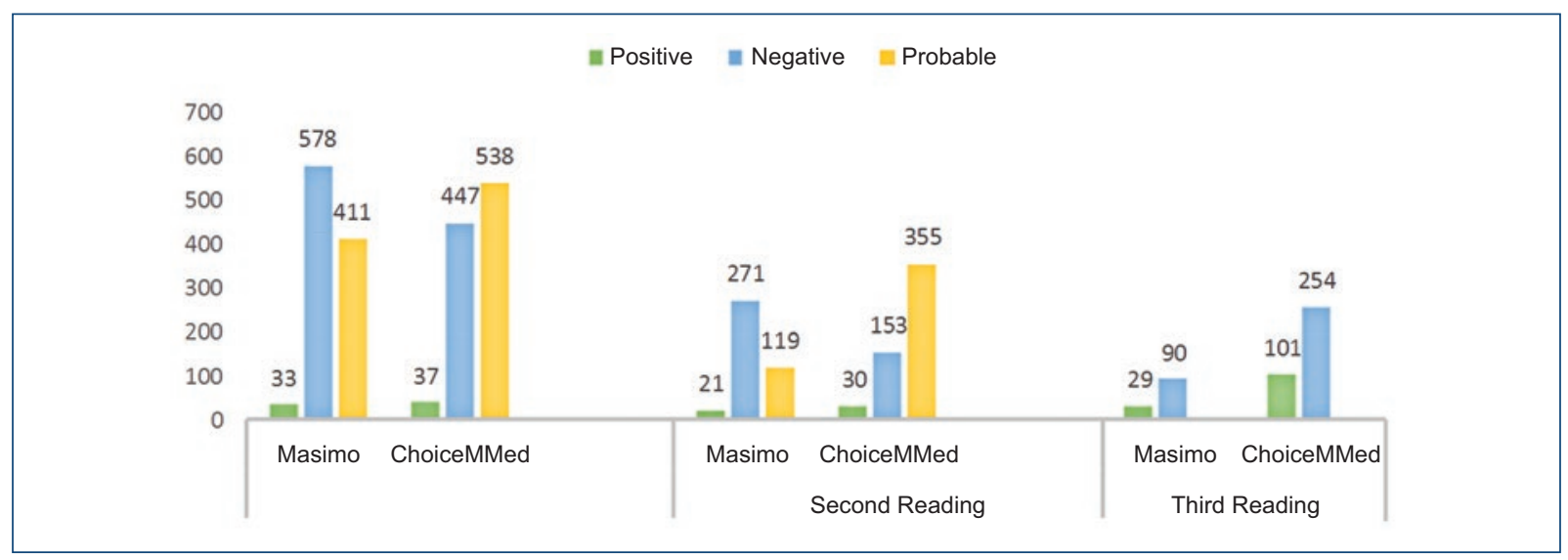

Figure 6. Total tests performed with both oximeters.

was performed in 41,445 NBs and a negative predictive value of $99.99 \%$ was obtained. Similar results were obtained in the database systematic review performed by Plana Maria et al. ${ }^{17}$, where they assessed around 21 trials where 10,000 apparently healthy NBs were studied, with a sensitivity of $76.3 \%$ and specificity of $99.9 \%$ being recorded. In our study, we found very similar results, with the negative predictive value of both oximeters being found to be $100 \%$, which indicates that both can similarly detect CCHDs; however, with the Massimo SET ${ }^{\circledR}$ oximeter, the CCHD diagnosis was made at the first reading, in comparison with the ChoiceMMed ${ }^{\circledR}$ device, by means of which CCHDs were diagnosed at the third reading.

Regarding false-positive readings, in our study, we observed that, with the Masimo SET ${ }^{\circledR}$ oximeter, positive predictive value is $26.5 \%$, whereas with ChoiceMMed $^{\circledR}$, it is $13.09 \%$, which indicates that the number of false-positive test results is moderate, and thus, several echocardiograms were performed without being necessary, which might generate more expenses, mainly with the ChoiceMMed ${ }^{\circledR}$ oximeter. Therefore, acquiring a Masimo $\mathrm{SET}^{\circledR}$ device might be more profitable; however, in different studies, these false-positive test results have been observed to have minimal impact on cost estimates $^{10}$ (Fig. 5).

With regard to time, we found that mean time with the Masimo SET ${ }^{\circledR}$ device was $5.38 \mathrm{~min}$, and in most patients, a single attempt was required to perform the test, in comparison with the ChoiceMMed ${ }^{\circledR}$ oximeter, by means of which mean time was 9.7 min, i.e., almost twice as long, and in two patients, it took up to $21 \mathrm{~min}$ to perform an oximetry test. Total performed tests and their results are shown in figure 6.

Another important point that needs to be analyzed is the perfusion index estimation with the Masimo $\mathrm{SET}^{\circledR}$ oximeter, which cannot be assessed with the ChoiceMMed $^{\circledR}$ device. The perfusion index is an evaluation of the pulsatile force in a specific control site and, as such, it is an indirect and non-invasive peripheral perfusion measurement. Early recognition of 
cardiocirculatory deterioration is important to avoid tissue hypoxia, which could ultimately lead to multiple organ failure. So far, clinical studies that have assessed the perfusion index clinical effectiveness have supported its clinical applicability, with one example being its association with the diagnosis of congenital heart diseases and even early sepsis ${ }^{18}$. In our study, non-critical heart disease was detected earlier with the perfusion index, as were patients with data consistent with sepsis.

\section{Conclusions}

We found specificity to be high with both oximeters, with a moderate sensitivity for the detection of CCHD.

However, we believe that the amount of time to perform the test (which is longer with the ChoiceMMed ${ }^{\circledR}$ device) should be assessed, as well as the number of false-positive test results, which can lead to increased costs.

In addition, as previously mentioned, although it is true that the negative predictive value is similar with both oximeters, CCHDs were detected earlier with the Masimo SET ${ }^{\circledR}$ device; in addition, the perfusion index can help detect non-critical heart diseases and data consistent with sepsis earlier.

There are multiple studies where pulse oximetry screening to detect critical heart disease has been established to be adequate and to be mandatory in some countries. There is a reduction in the costs of care, and especially in mortality, in these patients; therefore, we believe that performing the screening is imperative and not to having an FDA-approved oximeter should not be an impediment.

\section{Funding}

The present investigation has not received specific aid from public or commercial sector agencies or non-profit entities.

\section{Conflicts of interest}

The authors declare that they have no conflicts of interest.

\section{Ethical disclosures}

Protection of people and animals. The authors declare that no experiments were carried out on humans or animals for this research.
Confidentiality of data. The authors declare that they have followed the protocols of their work center on the publication of patient data.

Right to privacy and informed consent. The authors declare that no patient data appear in this article.

\section{References}

1. Sailh AF, Hamawand AM, Sattar RA. Role of pulse oximetry screening for detection of life threatening congenital heart detects in newborns. Kurdistan Journal of Applied Research. 2018;3(2):134-9.

2. Bernier PL, Stefanescu A, Samoukovic G, Tchervenkov Cl. The challenge of congenital heart Disease worldwide. Epidemiologic and demographic facts. Semin Thorac Cardiovas Surg Pediatr Card Surg Annu. 2010;13:26-34.

3. Sola A, Golombek SG. Early detection with pulse oximetry oh hypoxemic neonatal conditions. Development of the IX Clinical Consensus Statement of the Ibero-American Society of Neonatology (SIBEN). Int J Neonatal Screen. 2018;4:10

4. Torres-Cosme JL, Rolón-Porras C, Aguinaga-Ríos M, Acosta-Granado PM, Reyes-Muñoz E, Murguía-Peniche T. Mortality from congenital heart disease in Mexico: A problema on the rise. PLoS One. 2016;11(3):e0150422.

5. de-Wahl Granelli A, Wennergren M, Sandberg K, Mellander M, Bejlum C, Inganäs $\mathrm{L}$, et al. Impact of pulse oximetry screening on the detection of duct dependent congenital heart Disease: a Swedish prospective screening study in 39821 newborns. BMJ. 2009;338:a3037.

6. Mahle WT, Newburger JW, Matherne GP, Smith FC, Hoke TR, Koppel R, et al.; American Heart Association Congenital Heart Defects Committee of the Council on Cardiovascular Disease in the Young, Council on Cardiovascular Nursing, and Interdisciplinary Council on Quality of Care and Outcomes Research; American Academy of Pediatrics Section on Cardiology and Cardiac Surgery, and Committee on Fetus and Newborn. Role of pulse oximetry in examining newborns for congenital heart disease: a scientific statement from the American Heart Association and American Academy of Pediatrics. Circulation. 2009;120(5):447-58.

7. Mejia Salas H, Mejia Suarez M. Oximetría de Pulso. Rev Soc Bol Ped. 2012;51(2):149-54.

8. Martin GR, Beekman RH $3^{\text {rd }}$, Mikula EB, Fasules J, Garg LF, Kemper AR, et al. Implementing recommenden screening for critical congenital heart disease. Pediatrics. 2013;132(1):e185-92.

9. Jiménez Carbajal MG, López-Perez D, Fernández Luna CP. Relevancia de la detección de cardiopatías congénitas complejas mediante cribado con oximetría de pulso en recién nacidos aparentemente sanos en los establecimientos de salud. Arch Cardiol Mex. 2018;88(4):298-305.

10. Peterson C, Grosse SD, Glidewell J, Garg LF, Van Naarden Braun K, Knapp MM, et al. A public health economic assessment of hospitals'cost to screen newborns for critical congenital heart disease. Public Health Rep. 2014;129:86-93.

11. Carroll AE, Downs SM. Comprehensive cost-utility analysis of newborn screening strategies. Pediatric. 2006;117:S287-95.

12. Wong KK, Fournier A, Frutiman DS, Graves L, Human DG, Narvey M, et al. Canadian Cardiovascular Society/Canadian Pediatric Cardiology Association Position Statement on pulse oximetry screening in newborns to enhance detection of critical congenital heart Disease. Can J Cardiol. 2017;33:199-208.

13. Kochilas LK, Lohr JL, Bruhn, Borman-Shoap E, Gams BL, Pylipow M, et al. Implementation of critical congenita heart Disease in US newborns. Pediatic. 2013:132:e595-603.

14. Peterson C, Grosse SD, Glidewell J. A public health economic assessment of hospitals cost to screen newborns for critical congenital heart Disease. Public Health Rep. 2014;129:86-93.

15. Garson A, Allen H, Gersony W, Hohn AR, Pinsky WW, Mikhail O. et al. The cost of congenital heart disease in children and adults. A model multicenter assesssment of price and practice variation. Arch Pediatr Adolesc Med. 1994;148:1039-45

16. Riede FT, Worner C, Dahnert I, Mockel A, Kostelka M, Schneider P. Efectiveness of neonatal pulse oximetry screening for detection of critical congenital heart disease in daily clinical, routine-result from a prospective multicenter study. Eur J Pediatr. 2010;169:975-81.

17. Plana MN, Zamora J, Suresh G, Fernandez-Pineda L, Thangaratinam S, Ewer AK. Pulse oximetry screening for critical congenital heart defects. Cochrane Database Syst Rev. 2018;3:CD011912.

18. De la Peña Sanabria, Ochoa Martelo M, Baquero Latorre H, Acosta-Reyes J. Indice de perfusión periférica en la $\mathrm{UCI}$ neonatal: una respuesta a la monitorización no invasiva del recién nacido crítico. Perinatol Reprod Hum. 2017;31(2):85-90. 